\title{
Reimagining the ruins of the penalscape: Patrick Chamoiseau's carceral ruinology
}

\section{Sophie Fuggle}

Department of History, Languages and Global Cultures, Nottingham Trent University, Nottingham, United Kingdom

Corresponding author details: MAE 328, Clifton Campus, Nottingham NG11 8NS,

United Kingdom. E-mail: sophie.fuggle@ntu.ac.uk

Sophie Fuggle is Associate Professor of Postcolonial Studies and Cultural Heritage at Nottingham Trent University. She is author of Foucault/Paul: Subjects of Power (2013) and currently holds an Arts and Humanities Research Council early career fellowship for the project. "Postcards from the bagne" focused on the legacy of France's overseas penal colonies. 


\title{
Reimagining the ruins of the penalscape: Patrick Chamoiseau's carceral ruinology
}

\author{
This article explores Martinican author and educator, Patrick Chamoiseau's \\ evocation of the carceral ruin across his writing and, in particular, his novels. The \\ notion of a 'carceral ruinology' at play in Chamoiseau's oeuvre is explored in the \\ specific context of a 'penalscape' marked not only by today's prisons, camps and \\ detention centres but equally and increasingly by the remnants of historical forms \\ of imprisonment and internment. The article suggests that Chamoiseau's most \\ sustained engagement with the ruins of the prison, his essay on France's former \\ penal colony in French Guiana, Guyane: Traces-mémoires du bagne, published \\ alongside photographs by Rodolphe Hammadi, provides a conceptual tool for \\ thinking about the political stakes of these ruins. Such an approach also \\ circumvents existing critiques of the photo-essay and its recent republication as \\ an appendix to new images by Jean-Luc de Laguarigue. The article will argue \\ that Chamoiseau's writing of the carceral ruin is both a writing against history \\ and a writing against the prison. It will chart the movement from a reluctance to \\ describe the slave dungeon in Texaco, to the use of the same space as a means of \\ telling a different story in Un Dimanche au cachot before finally considering the \\ shift that occurs in L'empreinte à Crusoé where the island in its totality is \\ reimagined as prison. Where the presence of ruins allows different stories to be \\ told, the prison that disappears without a trace enables the return of the carceral \\ as much as the colonial via the myth of virgin territory.
}

Keywords: Chamoiseau; Hammadi; incarceration; penal colony; French Guiana; ruins

\section{Introduction}

Ruins of past incarceration and detention accumulate to haunt the twenty-first century. A strange longevity pervades the ruined landscapes of former sites of imprisonment. Even where the everyday requirements of community and people have gone, the lived reality of a prison is often far outlasted by the carceral remnant. The dungeon of a medieval township survives intact when all else has been destroyed. What are we to 
make of such ruins? Do they simply affirm the prison as a constant, necessary to the management and organization of large, complex populations? Or, might the ruin enable us to imagine something different, a future in which prison is not a default response to illegal activity but one in which it has become unsustainable, and incommensurate, along with so many other vicissitudes of capitalist social organization? Can the ruins of former sites of incarceration help us imagine today's prisons as ruins of the future? The writing of the carceral as ruin can be traced throughout the fictional work of Martinican author Patrick Chamoiseau. Taking an interdisciplinary approach which draws on themes of visual culture, ethnography, colonial heritage and history as well as literary production, this essay shows how Chamoiseau insists on the carceral as ruin in his storytelling while producing a critique of incarceration and its role within colonial and neo-colonial forms of oppression. As such the carceral ruinology that can be mapped across Chamoiseau's fiction works in conjunction with his more overtly political texts that tends to avoid direct discussion of contemporary forms of incarceration. To explain what is meant by 'carceral ruinology' here, we might cite Jason Parry's useful definition of 'ruinology' as 'the study of the speculative reconstruction of ruins' (Parry, 2020). In the simultaneous gaps and connections it creates between past and present, the ruin offers material proof and creative inspiration. The carceral ruin reminds us of a specific form of historical violence that persists today. In his studies of the ruins of the penal colony and the slave dungeon, Chamoiseau explores different ways in which encounters with these sites might resist romantic abstraction and instead resituate them within an ongoing discourse of abolition.

Our point of departure involves a rereading of Chamoiseau's most well-known text on the carceral, Guyane: Traces-mémoires du bagne (1994; referred to henceforth as Traces-mémoires) originally presented alongside a series of photographs by 
Rodolphe Hammadi taken in the early 1990s of the vestiges of France's former penal colony (colloquially known as the 'bagne') in French Guiana. In 2011 the essay was republished as an appendix to new images by Jean-Luc de Laguarigue who visited the same sites two decades after Hammadi. The decoupling of Chamoiseau's text from Hammadi's original photographs raises questions about the shifting critical status of Chamoiseau's writing of the penal colony and, specifically, his claims about the significance of the ruined buildings he encountered on his visit. In identifying potential problems with Chamoiseau's text and its juxtaposition with two different photography projects, this article suggests how his text, read as method, articulates key tactics for a writing of the carceral which is also a writing against the carceral.

In making a case for this form of writing, the essay provides a relatively broad survey of Chamoiseau's works to date. The intention here is not to be exhaustive or prescriptive but to emphasize the way in which the carceral and colonial are intertwined within the spaces that form the basis of Chamoiseau's writing. It also seeks to highlight the project of writing critically against the carceral as one which is both ongoing and for which the stakes are constantly shifting. In focusing on the literary imagination as a form of carceral ruinology, the article is situated within a wider research context taken up with mapping the extent and impact of convict transportation as global phenomenon embodied in the 'carceral archipelago' project led by Clare Anderson (2018). Developing an understanding of the carceral beyond the metropolitan prison to incorporate a complex set of spaces and infrastructures also echoes recent work carried out under the umbrella term of 'carceral geography' (Moran et al., 2018). At various points in the article, reference will be made to the 'penalscape' as a shorthand for articulating the multiple ways in which, since the eighteenth century, different forms of imprisonment: incarceration, detention, internment structure and organize the world 
across time and space. The ruins of the penal colony exist both independently from the present-day immigrant detention centre yet direct lines can be made between these sites, their populations, the practices taking place within and beyond their confines and the legal documentation defining their purposes and limits. In proposing this general use of the term, it is worth acknowledging that 'penalscape' has been evoked (James, 2007; Harkin and Meiners, 2016) in the very specific context of the failure of US public education to address the 'school to prison pipeline.' This approach challenges the uncritical link that is often made between poor literacy and school achievement amongst certain class and racial demographics to higher rates of incarceration. This existing usage seems of particular significance as a preface to the study of the 'carceral' in the writing of Chamoiseau, given his work as a prison educator in Fleury-Mérogis and Fortde-France as referenced in the preface to Prison vue de l'intérieur (2007) and Écrire en pays dominé (1997).

If the individual prison cell or dungeon dominates Chamoiseau's carceral ruinology, it is nevertheless just one of many sites or spaces which mark out the landscape as penalscape. Traces-mémoires bears witness to the forgotten, overgrown paths or trajectories that form the wider infrastructure of the penal colony. 'Les routes, les pistes, les Chemins de fer, les travaux d'assèchement, la construction des bâtiments, les canalisations, les digues, l'entretien des bourgs, l'activité administrative et commerciale, la mémoire artistique... pas un espace qui n'ait profité de l'industrie d'un bagnard.' (TM: 20) ${ }^{\mathrm{i}}$ Its multiple spaces are collected by Chamoiseau, 'Blockhaus... Bibiliothèque... Quartier disciplinaire... Prétoire... Quartier special... Les mots divisent l'espace.' (TM: 26) ${ }^{\mathrm{ii}}$ Lists accumulate in his writing interrupted by singular encounters with the hospital, the blockhouse, the cemetery, encounters that cause him to 
stop dead in his tracks and reflect upon the lives that once inhabited or passed through these spaces.

The argument set out in the essay is organised into five main sections. The first focuses on the photo-essay and its significance in providing a counter-narrative to official histories of the penal colony. The second section develops a wider discussion of the notion of the 'traces-mémoires' and ways in which existing scholarship on Chamoiseau has thus far taken up the theme of imprisonment. It also identifies the potential canonisation of Chamoiseau's Guyane essay and the threat this poses to the political force of his writing. This sets up the context for the third section focused on the idea of writing against the prison in relation to Chamoiseau's wider non-fiction œuvre. The final two sections of the essay focus on the fictional writing of the carceral ruin. Section four looks at the shifting parameters of Chamoiseau's exploration of the slave dungeon first in Texaco and later in Un Dimanche au cachot. Section five explores the trope of the prison island and the erasure of colonial histories in L'Empreinte à Crusoë. To conclude the essay, the contemporary legacy of France's overseas penal colonies is evoked briefly together with more general reflections on the persistence of prison islands as forms of migrant detention. The significance of Chamoiseau's writing on the carceral ruin is reiterated in terms of the further questions it provokes us to ask.

\section{In the ruins of the penal colony}

Between 1852 and 1953, over 70,000 convicts, comprising both political prisoners and criminals were transported to French Guiana. Transportation occurred from both mainland France and France's colonies. Although there were over 80 sites associated with the bagne, many of these have disappeared without a trace. Chamoiseau and Hammadi's photo-essay focuses on two well-known sites: the Îles du Salut and the 
Camp de la Transportation in Saint Laurent du Maroni. Additional lesser known sites are also featured. These include the church in the small town of Iracoubo whose murals were painted by the convict Huguet and the 'bagne des Annamites' located 40km from Cayenne and used to house Vietnamese prisoners. Following the closure of the bagne, many of the buildings belonging to the penal administration were abandoned for decades, left to ruin or, in the case of the Camp de la Transportation, sold to a private owner who rented its buildings out to families. ${ }^{\text {iii }}$ Chamoiseau and Hammadi's project took place following initial attempts to preserve and restore some of the architecture at these sites.

Two significant studies of the photo essay have considered it in isolation and, moreover, distinct to Chamoiseau's wider œuvre that often takes Martinique as its setting. Andrew Stafford's discussion of the project focuses on the collaboration between Chamoiseau and Hammadi, locating the 'photo-text' within a wider French tradition (Stafford, 2010). Stafford is somewhat dismissive of Chamoiseau's evocation of the 'trace' as belonging to a given moment within postcolonial writing heavily framed by poststructuralism and Jacques Derrida's notion of the 'trace' (Derrida, 1976). But the trace is also a term Chamoiseau takes from Glissant's Le discours antillais which he cites directly in the essay: 'notre paysage est son propre monument : la trace qu'il signifie est repérable par-dessous. C'est tout histoire.' (TM 15 ; Glissant, 1997: 32) Furthermore, as Gayatri Chakravorty Spivak emphasizes in her 1976 preface to $O f$ Grammatology, 'trace' in French has multiple meanings including path and track. These are of particular significance for Chamoiseau's exploration of the ruined sites of the bagne as is the negative sense of trace, evoked by Derrida, as implying absence, disappearance and a process of effacing. I will return to the idea of effacing towards the 
end of the essay where Chamoiseau's L'Empreinte à Crusoë is discussed in relation to the erasures that form part of the wider colonial project.

As part of a wider study on 'palimpsestic memory' (2015), Max Silverman provides a more nuanced, psychoanalytic reading of the photo-essay. Developing earlier material (Silverman, 2010), he explores Derrida's rerendering of Freud's notion of memory as palimpsest, a process of layering that is fragmented rather than systematic and which allows the juxtaposition of different experiences to emerge in the form of the trace. For Silverman, Chamoiseau offers a poetics of memory in his exploration of the ruins of the penal colony but a poetics that raises starker political questions about the relationships between different forms of imprisonment and exile.

Both Stafford and Silverman draw direct comparisons between Hammadi’s images and those of the defunct, ruined camps featured in Alain Resnais' Night and Fog (1956). The collaboration between Jean Cayrol's commentary and Resnais' montage (supplemented by Hanns Eisler's score) invite clear comparison with that of Chamoiseau and Hammadi. The aesthetic of barbed wire and call for accountability in Night and Fog refer as much to what was happening in Algeria as to France's complicity in the deportation of Jews from both the Occupied zone and the Vichy South (for a recent discussion, see Sanyal, 2014). However, it is only very recently that the specific role of the bagne within the Vichy regime has come to be more widely appreciated and publicly acknowledged. In an opinion piece published in Le Monde in November 2017, former French Minister of Justice, Robert Badinter, known for his longstanding criticism of France's prison system, declared the bagne in French Guiana a 'crime against humanity', focusing his attack very specifically on the Vichy regime which, he claimed, turned the penal colony into 'une veritable hécatombe' [a total massacre $].{ }^{\text {iv }}$ Badinter praised the hard work of historians including Michel Pierre 
(2017), Danielle Donet-Vincent (1992) and Jean-Lucien Sanchez (2013) for their extensive historical studies on the bagne.

These detailed histories of the penal colony need to be read in conjunction with Chamoiseau's text. Otherwise it risks becoming little more than a poetic aestheticization of the bagne and repeats the silencing it seeks to undo. Badinter's comments force the space of the bagne into the same historical context as the gulags and concentration camps that precede the moment in which Chamoiseau finds himself writing, as emphasized in the autobiographical Écrire en pays dominé (17; henceforth Écrire). Defining the political task of writing in the aftermath of twentieth century atrocity and the regimes of slavery and colonialism that preceded it-- becomes more obscure now that it no longer operates as a weapon against direct violence and imprisonment. 'Heureux ceux qui écrivent sous la domination de l'âge dernier : leurs poèmes peuvent faire balles, et conforter l'espoir du nombre de leurs impacts.' $(18 \text {, italics in original })^{\mathrm{v}}$ Chamoiseau's writing both of the bagne and other forms of carceral ruin are imbued with the anxiety that comes with a form of (post)colonial oppression that can be less clearly articulated. Henceforth, references to 'prisons', 'cells' and 'jailors' take on a metaphorical sense for the writer. He takes inspiration from other writers such as Rabemananjara, Dostoyevsky and Glissant who all teach him more about his own psychological imprisonment than they do about concrete prisons. In articulating this sense of conflict that comes from living in the wake of French departmentalisation, he offers a lens for reading the histories of the penal colony (as well as other spaces) as reconstructed by contemporary historians such as those mentioned above. He reminds us that writing history must also be a writing against history. In other words, the ongoing task is to identify the stories told and untold that fall outside of official and dominant narratives. 


\section{Exploring the penalscape. Between stone and forest.}

Tranposing Chamoiseau's discussion of the 'Traces-mémoires' to a wider carceral and, moreover, colonial context via his other texts also offers a way out of a potential fixation on the specific yet fragmented space of the bagne. This is already apparent in Chamoiseau's evocation of the 'Traces-mémoires' in Écrire where a more general definition of the 'mémoires' which emanate from the 'traces' is offered. The 'traces' are concrete markers such as a 'tree' or a 'song' evoking different emotions and associations without coalescing into something resembling a monument. They remain ephermeral and thus resist an affirmation of the colonial past from which they nevertheless emerge. $(130-1)$

While Traces-mémoires is referenced in more comparative studies taken up with Chamoiseau's wider œuvre, this has often been cursory rather than as a sustained analysis. It is unsurprising that less focus was given to the carceral prior to the publication of Un dimanche au cachot in 2007 (henceforth Un dimanche). In her study of the Antillean space of Chamoiseau's writing, Lorna Milne (2006) largely omits the carceral, focusing on the sites she considers intergral to his work: 'the hold of the slave ship'; 'the market'; 'the Créole habitat'; 'the forest' and 'stone and bones'. McCusker's analysis of memory in Chamoiseau's work, draws on many of the same spatial themes as Milne but explores more directly the idea of the 'Traces-mémoires' as a practice that can be extrapolated to other contexts beyond that of the bagne (McCusker, 2007: 102). The importance of McCusker and Milne's work for a carceral ruinology lies in the central role they attribute to forest and stone. Indeed, Milne points out that Chamoiseau's evocation of the forest takes on an increasingly political function in his fiction writing (Milne, 148). This political dimension which Milne locates most forcibly in Biblique des derniers gestes but also in L'Esclave vieil homme et le molosse is linked 
in particular to the identification of the forest with a rejection of slavery both as a space of physical retreat and in terms of its symbolism. In a 2014 essay, Chamoiseau describes his oft-referenced concept of the 'pierre-monde' [stone-world] as that which allows him to stay grounded when faced with the vertiginous openness of Glissant's 'tout-monde' [total-world] (Glissant, 1997). The 'pierre-monde' is akin to a talisman or philosopher's stone (Chamoiseau, 2014: 102-3). As such it should be understood as a force as much as a material entity. These enigmatic definitions echo the series of paradoxes set out in Écrire:

Pierre, car au-delà du possible des représentations humaines.

Pierre, car déjà là et encore à construire.

Pierre, car fluide et incertaine et de haute densité.

Pierre, car en nous et tout autour de nous, en vouloir et matière.

Pierre, car d'ombre et de lumière, de conscient et d'inconscient, du chaos des contraires dans l'Unité pour nous inconcevable.

Pierre, car de conscience poussée jusqu'à l'intelligence d'une manière primordiale. $(313)^{\mathrm{vi}}$

How are we to situate the stone or stones which denote the vestiges of the bagne within this understanding of the pierre-monde? Is it possible to read these paradoxes into the carceral ruins that also refute easy and reductive definitions, which resist but also inspire imaginings of the lives, the experiences and the sufferings that converged within the penal colony? It is perhaps via this complex and philosophical understanding of the stone that all the while insists on its materiality and the impact of this materiality on the world we inhabit, that we can read Chamoiseau's affirmation of the ruin and its maintenance as ruin (a paradox in itself) over against the restoration of penal architecture. 
Scholars who have subsequently identified the 'carceral' as a key theme have done so in the later context of the publication of Un dimanche with Traces-mémoires referenced as a point of comparison (Selao, 2015; Simek, 2016; Feyereisen, 2017). The primary focus of such analyses is the emancipatory potential of storytelling. To offer one example here, in her comparative study of Un Dimanche, Traces-mémiores and J.M G Le Clezio's Quarantine, Feyereisen describes this in terms of a heightened 'selfconsciousness' and 'community spirit' (Feyereisen, 2017: 5). These possibilities are not something I wish to dispute but rather would like to see situated in the context of a more overtly political critique of incarceration as colonial legacy. More recently, Forsdick (2018) has placed Traces-mémoires in conversation with other writing on the bagne, acknowledging the methodological value of Chamoiseau's 'traces' for subsequent engagements with French colonial and penal heritage. Forsdick emphasizes the 'transnational' stories belonging to the history of the bagne. These are traces or paths which Chamoiseau evokes but does not pursue in his references to the non-European populations: 'Amérindiens, esclaves africains, immigrants hindous, syro-libanais, chinois...' (TM: 13) all of whom contribute to the history of French Guiana and came into contact with the convict population and penal administration. ${ }^{\mathrm{vii}}$

The Traces-mémoires thus do not consist of the location of an object or origin but involve retracing steps, rereading stories, reimagining the space of the bagne in a way that contests singular dominant narratives of colonialism. However, there is also the risk that retracing can become its own form of monumentalisation. As mentioned above, Chamoiseau's essay was originally published in 1994 alongside Hammadi's photographs, and subsequently republished with new photos by Jean-Luc de Laguarigue in 2011 entitled A.P. Bagne. In his analysis of the original collaboration, Stafford suggests Hammadi provided a different type of imagery to Laguarigue who had been 
Chamoiseau's long-time collaborator. Stafford also suggested Chamoiseau and Laguarigue's other collaborations lacked the 'simplicity or power' of the Tracesmémoires project with Hammadi (154). Stafford questions whether the publisher of the original photo essay, the Caisse nationale des monuments historiques et des sites was a potential impediment to the political critique of patrimoine [heritage] at work in Chamoiseau's text and Hammadi's images. Publishing with CNMHS risked recuperation into official, institutionalized discourses on history and heritage (141; 152). This criticism must surely only intensify with the arrival of Laguarigue's book. Where Traces-mémoires most closely resembles a paperback guidebook in size and presentation, A.P. Bagne is unequivocally a coffee table art book. It is almost six times the size of Traces-mémoires and bears a woven cloth hardback cover embossed with the title, evoking the A.P. bricks that have become valuable collector's items.

Hammadi focused on the bagne as a series of frames, his photography often producing a mise-en-abyme of former cell windows and door frames emphasizing the bagne as caught up in a claustrophobic set of references. The selection of images works in parallel with Chamoiseau's text which also identifies the 'grille' which contains and divides: 'Dans l'ombre de la cellule, le quadrillage de la grille d'où tombe la lumière. Carré, rectangle ou demi-lune. Ce n'est pas seulement la lumière que la grille déstructure, mais le vent, les odeurs, des bouts de ciel, des tranches de murs, des carrés de vie très souvent immobiles.' (TM: 39) ${ }^{\text {viii }}$

Conversely, Laguarigue's images, enhanced by the larger format, focus on the texture of the bagne most notably in the multiple layers that can be read in the peeling paintwork of the cells. The reproduction of Chamoiseau's now out-of-print text endorses Laguarigue's project whilst authenticating Chamoiseau's claim to canonical status as part of the posthumous story of the penal colony. Chamoiseau's earlier search 
for the Traces-mémoires juxtaposed with glimpses of human existences in and around the ruins of the Camp de la Transportation captured by Hammadi; a golden retriever, chickens, a pair of trousers drying in the sun are displaced by images of the Camp as Monument in Laguarigue's photographs. In lending his writing to a new set of images, Chamoiseau's text becomes an act of retracing his own steps, a form of overwriting which risks effacing the traces, the embodied experiences of the different populations he tries to locate in these ruins. It is against this canonization that a carceral ruinology must guard.

\section{Against prison writing}

Above we suggested that Chamoiseau's work bears the question of how to write a history that is at the same time a writing against this history and, indeed, its legacy. As acknowledged in Traces-mémoires, his approach is indebted to Glissant's search for the traces of histories across the Antillaise landscape and the call to deconstruct official forms of colonial heritage and writing. If Chamoiseau's writing on the carceral ruin takes up this task, to fully grasp what is at stake here, we need to juxtapose this writing on the penal colony and the slave dungeon with his resistance elsewhere to producing commentary on the contemporary prison. In the collectively produced Manifeste pour les 'produits' de haute nécessité published on the occasion of the widespread 2009 social movements in the French Caribbean, French Guiana and Reunion, references to forms of imprisonment are either metaphorical: 'les camps sans barbelés du chômage structurel né du capitalisme' (9) ${ }^{\text {ix }}$ or implicit : 'archaïsmes coloniaux' [colonial relics] (11). Similarly, the 2007 essay Quand les murs tombent [When the walls fall] coauthored with Glissant,-evokes the historical atrocities of slavery and the Holocaust against a backdrop of contemporary border control. However, in making these 
connections, the essay arguable does not go far enough in its critique of the use of different types of wall to enforce and legitimise global social inequality. An analysis, most notably developed in the US context by Davis (2003) and Alexander (2010), which links poverty, racism and incarceration is frustratingly absent from Chamoiseau's critique of contemporary forms of capitalism, globalisation and their colonial underpinnings.

In his preface to Prison vue de l'intérieur, a collection of accounts from those working inside prisons, Chamoiseau makes the intriguing point that the prison has never featured in his 'univers romanesque' [literary universe] (8). He explains that he has never written about prison because prison has always been something closed off to him. Despite many years as an educator in penal and juvenile institutions in France and Martinique, Chamoiseau identifies a paradox whereby everyone who enters the space of the prison remains somehow excluded from it. There is something about prison which remains opaque.

The prison as featured in Chamoiseau's literature is thus nearly always already a ruin. However, it is possible to locate two notable exceptions where the space of the functioning or 'live' prison is directly evoked in his writing. Consider first, Chamoiseau's. little-known play written in 1975, Une manière d'Antigone. As Knepper suggests, Chamoiseau appears to be following Aimé Césaire (whose 1969 Une Tempête reimagined Shakespeare's The Tempest in a Caribbean context) in his reworking of a classic Western play (Kneppers, 2012: 39). The contexts for Chamoiseau's reimagining of Sophocles' Antigone were the social tensions and police brutality impacting Martinique during the 1960s and 1970s. The action is set in the prison in Fort-deFrance. Following a youth rebellion, Creon orders that the dead are left on display as a 
warning. As in the original, Antigone goes against this order and is subsequently imprisoned.

If the play does not seem to count in what Chamoiseau refers to as his 'univers romanesque', this is perhaps because the starting point for the action is not inside but outside the prison in the form of the rebellion and the subsequent display of the dead youth. At stake here is a critique of the public spectacle of torture and the repeat performances of suffering demanded of the enslaved and/or incarcerated body. Yet, this early work perhaps fails to escape the double bind that requires the repeat performance it seeks to do away with.

The second notable example where Chamoiseau directly evokes the interior space of the working prison is his account in Écrire of the prison library and the young inmate whose reading and writing talent he inspires and takes inspiration from. The account while autobiographical rather than fictional is nevertheless important as a sustained account of a certain aspect of life inside Fleury-Mérogis prison. As Kullberg points out, it is one of the few spaces in Paris that Chamoiseau elucidates and plays a key role within the autobiography in framing his experience of mainland France (Kullberg, 2013: 89).

What we might take from Chamoiseau's account is not about writing, writing about prison, writing the prison but, rather, about reading. Indeed, Kullberg identifies reading as the starting point for writing here. Reading as something both difficult, often near impossible and, yet, necessary within the space of the prison. Chamoiseau is engaged in a reading of the prison focused around reading in prison. The writing that emerges, both his account and the writing produced by his young student might be considered as a writing not about prison but the opposite, a writing against the prison or, at the very least, a writing that is against prison writing in the common forms such 
writing takes. In addition to tales of transgression à la Jean Genet or the romanticized prison memoirs of political figures such as Dreyfus, we should foreground the selfaggrandizing escape narratives of Henri Charrière’s Papillon (1969) and René Belbenoit's Dry Guillotine (1944) that constitute a large part of the canon on prison writing and especially those written about the bagne. Such writing seems liable to affirm the prison and the suffering it produces.

Chamoiseau's treatment of the live prison in Antigone and Écrire-should thus not be read as in contradiction to the statements he makes about writing the prison in the preface to Prison vue de l'intérieur. Instead citing these texts is necessary to present a more nuanced understanding of his political engagement with the space of the prison. This includes a refusal, even when writing about the prison, to reduce it to a certain type of sensationalist material. By recasting the carceral spaces located within the slave regime as already ruins, Chamoiseau finds a way in his later works, Texaco and the more recent Un dimanche, to negotiate this spectacle of suffering without lending legitimacy to it.

\section{Refusing to describe. The case of the slave dungeon.}

In her discussion of Traces-mémoires, Feyereisen offers an indepth account of the language of negation adopted by Chamoiseau in his presentation of the historic sites of the bagne (Feyereisen, 12). He cannot and will not [ne peux - et ne veux pas] explain the direction of the tour or locate the main entrance to the bagne (Traces-mémiores, 22). ${ }^{\mathrm{x}}$ The monument and the trace-mémoire that issues from this space are both 'indescribable' [indicible]. At stake is a refusal to document, take stock or archive of the ruins he encounters. But this negation is also an affirmation. 'La visite n'est pas à faire, elle est à vivre.' [The visit is not done, it is lived] At stake here, and of key importance 
in Feyereisen's analysis, is the encounter with the physical carceral ruins located across French Guiana as affective, embodied experience. And it is this embodied experience as affirmation via negation that we also find in Chamoiseau's fictional accounts of the carceral ruin.

In giving voice to his (fictional) characters, Chamoiseau denies the possibility of their recuperation into dominant historical narratives. To describe here also often involves a refusal to describe. Early on in Texaco, Esternome refuses to describe the 'cachot', the slave dungeon, to his daughter Marie-Sophie, all the while evoking the horror its ongoing presence post-emancipation continues to incite. The dungeons continue to scar the landscape for those who remember what they are. The passage plants the seeds of imagination for Chamoiseau's later autofictional encounter with the 'cachot' in Un dimanche. For Esternome, the sight, even obscured, of the former dungeons causes him to 'tremble' [frissonner] (T: 36/50). He requests the right not to describe it despite having already referred to its grey stone structure as conserving a 'bottomless sadness' [tristesse sans fond]. But the rationale for not describing or illustrating the dungeon in further detail is what is of key significance here. By refusing to describe the dungeon at length there is a refusal to acknowledge or claim responsibility for its existence. The dungeon belongs to those who constructed it. They are responsible for its existence. To refuse to describe it, is to refuse to affirm its existence or, perhaps, to acquiesce to its existence. 'Permets-moi de ne pas te décrire le cachot car tu comprends, Marie-Sophie, disait mon papa, il ne faut pas illustrer ces choses-là, afin de laisser à ceux qui les ont construites la charge totale de leur existence.' $(36)^{\mathrm{xi}}$ This precision is key to understanding Chamoiseau's own reticence in describing the prison other than as a ruin. To describe a slave prison in terms of its ruination allows a reference, a remembering of its former use without agreeing to this 
use or, via fiction, reproducing this use in his writing. Read retrospectively in the context of Un dimanche, Chamoiseau's reference to the cachot in Texaco reads as a tentative, cautious approach to writing the space. It is as if the author is only as willing to get as close to the ruined edifices as the characters are. Thus with Un Dimanche we can see a shift not in Chamoiseau's own engagement with the space either as writer or narrator but in that of a younger generation for whom the physical, visible ruins appear to have less bearing all the while the legacies of slavery and departmentalisation continue to define and limit their own futures.

However, in addition to its early reference to the dungeon, Texaco also offers an example of how Chamoiseau is able to produce encounters with the carceral that enable a rewriting of established narratives. This involves his rewriting of the Mont Pelée volcano and its survivors. Of the 29,000 inhabitants living in and around Saint Pierre, Martinique in 1902 when the volcano erupted, only three are thought to have survived. Best known is Louis-August Cyparis, who was being held in a poorly ventilated dungeon for disorderly behaviour. Afterwards he toured the world with a circus troupe displaying his burns as a kind of miraculous freak survivor. According to common mythology, he is said to have predicted the eruption and got himself thrown in jail on purpose. Chamoiseau's reworking of the events of April 1902 neatly embody the stakes of his carceral ruinology which he situates within a historical context itself dependent upon the act of storytelling rather than historical accuracy for its authenticity.

Chamoiseau rewrites the story of Cyparis. Esternome becomes the one who discovers the prison while in search of his beloved Ninon. But there are not one but two survivors. The horrors which await outside the cell combined with the implacability of Esternome in his search force them back inside the prison (151). Preempting once more Un dimanche, the prison becomes a temporary safe haven. This reimagining of prison 
echoes Chamoiseau's discovery recounted in Traces-mémoires that the Camp de la Transportation has become a home to a new set of residents. 'On fait havre d'un cachot' [a cell has been turned into a haven] (TM: 36). In Texaco, the survivors remain anonymous amongst the ruins, their story is yet to become one of legend. Chamoiseau releases Cyparis from the obligation to endlessly perform his trauma and display his burns. Instead, the story is retold via Esternome's inability to describe what happened. The reversal whereby the prison becomes a place of protection and safety alerts us to the extent to which the outside world has become a site of destruction in which stone and flesh have become one.

In Un dimanche, Chamoiseau returns to the space of the slave dungeon that Esternome refused to describe in Texaco. The unknowability of the prison in question here is the motivation and reactions of Caroline, the adolescent girl that Chamoiseau is sent to find. This unknowability is coupled with the unimaginable suffering of the dungeon that Chamoiseau forces himself to reimagine as a means of negotiating the space. Un dimanche involves the intertwining of two stories, past and present, while at the same time the story of 'Oubliée' [which translates as 'Forgotten'] offers a paratext to his earlier novel, L'Esclave vieil homme et le molosse.

The story Chamoiseau recounts to the troubled youth is ultimately one of emancipation and empowerment similar to those that Maître Djobeur Pipi invents to tell Marguerite Jupiter's children in Chronique des sept misères (194). Earlier in his life, Pipi spends a brief spell in prison and this is, interestingly, where he excels in the art of storytelling (74). As with the Traces-mémoires that Chamoiseau located amongst the ruined, overgrown architecture of the bagne, the space of the dungeon and the prison become a conduit for telling a different story to the ones forgotten by history. Stories of what might have happened. But in case this deliberate ambiguity is lost on the reader, 
Chamoiseau adds a final twist to the narrative of Un dimanche. A final phone call, acting as a coda, sees the owner of the property on which the 'cachot' is located inform Chamoiseau that the local heritage society have determined the structure cannot possibly be that of a slave dungeon. This marks the return of official history and its unequivocal claim to authority. Yet such a claim is moot. It offers too little, too late in light of the imagined history produced within the space of the non-dungeon. As Chamoiseau-narrator responds, ‘Ah... Et ça change quoi?’ (349) ${ }^{\mathrm{xii}}$

The carceral ruin is developed in Chamoiseau's novels not as a site of action but rather as one bearing witness to the possibility or even ethical imperative to tell a different story. The freedom such stories achieve is from the burden of retelling and reperforming histories of oppression. However, Chamoiseau's use of paratext and what Silverman has described as 'palimpsestic memory' takes on a more complex, philosophical form in L'empreinte à Crusoé. Here palimpsestic memory is the product and in turn produces different forms of amnesia both individual (the sailor's memory loss) and collective (the crew's ability to distinguish the island). A reversal has occurred. The narrative no longer takes place amongst the ruins of a prison located on an island, now it is the island itself that constitutes the prison.

\section{The île carcérale}

The arrival of the first convicts in French Guiana in 1852 was embraced by the governor of the colony as a bright new dawn. Many had volunteered for transportation, promised a role in the development of the colony following the end of their sentence. Plans were drawn up for a commemorative column to be positioned on Île Royale. The task of erecting the column was to be undertaken by the convicts, a symbol of their commitment to both penal and colonial projects. It was to be completed with an eagle 
sat atop an orb. Four plaques were to be positioned at the base including one that read 'Repentance is Salvation' (ANOM GUY 2701 COL 112). The archives include preliminary plans and costings from a foundry in Paris for the smelting work involved in producing the eagle and its orb. It is not clear from either the archives or later accounts whether the column was ever erected. Most likely it was fairly swiftly abandoned along with the utopian ideals with which the bagne was inaugurated.

In his encounter with the literal and figurative ruins of the carceral in Tracesmémoires, Chamoiseau affirms its existence as ruin, counterposing it to the memorial, the restored buildings or edifices and the commemorative plaques and statues which affirm what he calls history, histoire with a capital ' $\mathrm{H}$ ' (TM: 14). There is no set way to approach the ruin, no set route. Traces-mémoires subverts the idea of the guided tour or circuit. Chamoiseau describes his movements through these spaces as a form of erring, a wandering [divagation] that he distinguishes from flânerie. (TM: 43). However, we should be wary of Chamoiseau's claim here. This call in relation to the vestiges of the bagne is somewhat disingenuous not least given his own exploration of these are limited to sites that have been most comprehensively preserved with some of these accessible only as part of guided tours. Today a trip by catamaran to the Iles du Salut costs around $€ 50$ with Devil's Island off-limits to tourists.

However, in his 2012 reworking of the Robinson narrative, L'empreinte $\grave{a}$ Crusoé, the 'île carcérale' [prison island] and its ruination are explored to greater effect via the figure of the stranded sailor. The deserted island is described as a prison by the sailor due to, one assumes, its topographical and psychological limits. It is only when we learn the 'real' circumstances of his arrival from the captain (the actual Crusoe of Defoe's story) that we realise it was always intended as a space of exile and confinement for a Muslim sailor who opposed the transportation of Black slaves aboard 
the ship. The initial attempts of the sailor at 'colonisation' on and of the island embody the utopian fantasies of the penal colony. Chamoiseau brings home the multiple ironies whereby under colonialism the treasure island is always also a prison island and the colonized become unwittingly complicit in pursuing colonial ideals as if their own. This is best captured in his description of the island as a prison 'de nacre' [mother-of-pearl] combining the idea of treasure embodied in the image of the prized pearl with the claustrophobia of being trapped inside a shell (EC: 179). The time of development and ruination are accelerated taking a matter of years rather than decades or even centuries. This allows the sailor to witness the ruination of his own attempts at colonizing the island. Amongst these are the ministries he establishes, his flag and his naming of places (EC: 56). The first stage of ruination occurs when he gives himself over to 'protecting' the island and his person from the intruder.

The figures of explorer, administrator and convict are collapsed into the person of the sailor. At the same time, he is aware he is not the first to have arrived here. Different, other histories confuse his sense of time and identity compounded by his amnesia: 'mon imagination à partir des objets et ma mémoire obscure ne faisaient que chaos : toute possibilité de mettre au clair mon origine réelle disparaissait alors...' (EC: 32) $)^{\mathrm{xiii}} \mathrm{We}$ are confronted by an individualised experience of the 'Traces-mémoires'. This is articulated in terms of the spaces that exist between the words and sentences of the waterlogged texts the sailor discovers. His existence on the island is described in terms of rewriting these words, 'élargir l'espace entre les phrases, entre les mots et leurs réalités' (33). ${ }^{\mathrm{xiv}}$

Throughout the narrative, the sailor describes his movements about the island in terms of spirals. Chamoiseau's evocation of the spiral draws heavily on the work of Haitian writer Frankétienne, a key figure in the spiralist literature movement of the late 
1960s. Spiralist literature eschews traditional Western literary forms, instead providing 'a nonlinear, fragmented collage of these genres' (Cobb Wittrock, 2010: 105; see also Douglas, 2009) Described as a récit, Chamoiseau's version of the Crusoe story embodies these aims, disrupting the temporality of the original story, offering a collageeffect both in terms of its structure (shifting between the abandoned sailor's account and the captain's journal) and use of paratext (in the form of a postface entitled 'atelier' comprising Chamoiseau's rough notes and cuts) and in the protagonist's attempt to piece together his life story via fragments of waterlogged books.

To move in a spiral offers a resistance to following the same path in a neat circuit or linear route between two fixed points. In this respect, it evokes the negation of fixed trajectories or circuits emphasized by Chamoiseau in his exploration of French Guiana and the vestiges of the bagne. Yet, to move around the island in spirals is initially part of an attempt to colonise the space, to grasp the island first in its totality and with each subsequent, smaller ring, its minutiae. It is initially a tactic intended to track the intruder whilst avoiding being tracked. But at the same time the spiral suggests ever-decreasing circles, an intensification towards a centre one may never reach. Herein lies the sailor's paradoxical relationship with the island. The spiral provides him with a pattern, a means of inscribing his own confused existence within the complex space of the island. Yet this inscription of himself turns out to be incommensurate with that of the captain who views the island not in its complexity and different but, rather, its homogeneity. 'Rien ne ressemble plus à une île qu'une autre île.' (EC: 186) ${ }^{\mathrm{xv}}$ On his return to the island, the captain describes the sailor as speaking in spirals as a means of describing the incomprehensibility of the sailor's utterances.

Where Defoe's Crusoe is focused on the establishment of a microeconomy based around cultivating and farming the island's natural resources and Tournier's 
Crusoe is taken up with the negotiation of the relationship with the 'other', the figure of Friday, Chamoiseau moves past these stages - the colonial and postcolonial to what might be termed the 'ecological'. In other words, the complex ecosystems of the island space are recentred in the narrative so that the island is no longer simply a site on which to assert and judge human mastery over nature or a backdrop against which human relationships play out. It is in the movement towards a new relationship with the island that marks the sailor's realisation of humanity's failed project to colonise and dominate its space. Such a project will always fail since it is predicated on the idea of the island as 'deserted', an empty space upon which all human and specifically colonial desires and pathologies might be projected: 'Je me répétais sans cesse que c'était un organisme vivant, pas une île désertée ; pas une prison hostile mais une vie qui avait réussi à se sortir d'une lave sans âme...' (EC : 180) ${ }^{\mathrm{xvi}}$

The footprint, the owner of which is never determined, might be read as metonym for the Anthropocene (although Chamoiseau would not necessarily use this term). It is the fixation on the footprint that maintains the island as prison. In his initial attempt to secure the island against the invisible intruder, the space becomes a fortress ('ma caverne fortifiée' [my fortified caverne], 52) whilst also acting as a prison for the sailor. His surveillance is met with the sense that the other is also 'patrolling' [patrouiller] the island (53). Yet, it is an awareness of the presence and persistence of the footprint that is key to the changing relationship with the island undergone by the sailor:

‘je ne regarde plus l'empreinte pour tenter de la comprendre, ou de lui deviner une quelconque origine ; elle était posée-là, inscrite dans la masse argileuse que le sable habillait ; elle n'avait pas d'âge, ni commencement ni fin ; sans doute avait-elle été là avant même que je n'existe sur terre ; peut-être qu'elle était tombée de la préhistoire de ce monde, et que ses rapports avec la forme d'un pied ne provenait que de mes pauvres 
sens ; je m'efforçais simplement de percevoir ce qu'elle était : une forme ineffable, plantée-là, sur le temps et la surface du monde...' $(\mathrm{EC}: 217)^{\mathrm{xvii}}$

Tragically this is an experience and awareness that comes both too early and too late. When the captain returns to the island with his crew they fail to learn from the sailor who dies at their hands due to the threat he poses to the order of the ship and its mission. Chamoiseau's Crusoe is a story of what will have been, the future anterior. His version is both a postscript and preface to Defoe's Crusoe. The captain, we discover at the end, is Defoe's protagonist who himself ends up stranded on the island without having learned anything from the sailor he once abandoned there. 'Je ne trouvai aucune trace d'une vie humaine [...] Ce n'était qu'une île des temps perdus et des éternités fixes. Quant à l'empreinte, il nous fut impossible de la localiser nulle part.' $(\mathrm{EC}: 231)^{\mathrm{x} v i i}$ The story becomes a cautionary tale about the ease with which the vicissitudes of colonialism and capitalism are seemingly effaced and forgotten. The myth of virgin territory persists allowing for neocolonial claims on space to be made often under the insidious umbrella of 'development'.

Considering once more the spaces once under the jurisdiction of the penal administration in French Guiana, we might apply the same caution in our focus on a limited collection of ruins and restored buildings. Miranda Spieler draws attention to the temporary forest work camps, composing much of the penal colony's operation. These sites have mostly disappeared, now covered with secondary rainforest. But we should not regard this as a 'return' to a previous natural state. Instead, Spieler suggests that : '(French) Guiana was not a place where human history had yet to begin, but one where human traces on the land tended to vanish.' (Spieler, 2012: 2) Following Spieler, the absence of ruins, the erasure of the carceral must necessarily constitute a 'wordless trace' (4) that alerts us to a colonial project that was less a failure than deliberately self- 
abortive. Returning to Badinter's claim that the bagne constituted a 'massacre', is not perhaps the greatest success of France's penal colony in French Guiana (in distinction to Australia and also New Caledonia), the fact that most of the 70,000 'undesirables' ejected from France and its colonies, disappeared without a trace, leaving no descendants or legacy?

\section{Conclusion. The return of the carceral}

More than Chamoiseau's other novels which use the carceral ruin as a starting point for telling different stories allowing for a rupture with this carceral past, L'empreinte offers a bleaker image of the way in which colonial violence often appears to leave no trace thus leaving space for its resurgence. It also reminds us of the fine line between prison and treasure islands, something that bears thinking about in relation to the present-day situation on Nauru, Manus and elsewhere. In his opposition to heritage restoration initiatives (TM: 45), Chamoiseau proposes an impossible distinction between ruination and restoration. Such a distinction was already moot at the sites he visited in French Guiana in the mid-1990s. Just as Davis and Alexander read the legacy of slavery into today's prison system in the United States from chain gang to warehousing, the legacy of France's penal colonies is integral to the contemporary penalscapes of French Guiana and New Caledonia. In New Caledonia, the only prison, 'Camp Est' is located on Île Nou using former penal colony buildings. Its overcrowding and poor conditions led the Observatoire International des Prisons branding it the 'bagne postcolonial' in 2012. In Saint Laurent du Maroni, a new prison is being built aimed at housing, in particular, inmates from the border communities along the Maroni River. The prison represents a heavily securitized response to illegal activity resulting not simply from social inequality but also from ways of existence and exchange incommensurate with notions 
of territory imported from Fortress Europe. It affirms the ongoing treatment of French Guiana as a colony by French government officials, regulating and defining the space according to utopian colonial ideals that display limited concern for the specific dynamics of the space and its populations.

In his recent response to the refugee crisis in the Mediterranean, Frère Migrants (2017), Chamoiseau offers a notion of hospitality that might supplement the Tracesmémoires as method whereby one opens oneself towards the other forgotten or maligned by history. Beyond the context of excessive border controls and refugee camps, the poetic imagination called into the service of this hospitality might equally be applied to other sites of suffering including that of the prison. Moreover, in encountering the carceral ruins of French Guiana and elsewhere, might we imagine, instead of a different past as Chamoiseau frequently does, a different future? Can we imagine today's prisons as the ruins of the future? This is the question I opened with. It is not a question Chamoiseau poses himself. Yet he does repeatedly draw our attention to the ruin, the complex, ambiguous relationship between built and natural environment that constitutes the legacy of the Anthropocene. It is the ambiguity that means the ruins can be reimagined as a safe haven, a space in which different stories can be told and heard. Perhaps we shouldn't be afraid of the ruins but rather the deep and disturbing irony that turns prisons into places of refuge while the world is collapsing outside?

Acknowledgements. This work was supported by a British Academy small grant [SG162446].

\section{References}

Archives Nationales d'Outre Mer - Série Géographique Guyane (GUY) 2701 COL 112. 
Alexander, M. (2010) The New Jim Crow: Mass Incarceration in the Age of

Colorblindness. New York, NY: The New Press, 2010.

Anderson, C. (ed.). (2018). A Global History of Convicts and Penal Colonies. London: Bloomsbury.

Badinter, R. (2017). Le Bagne de Guyane, un crime contre l'humanité. Le Monde, 24 November. Available: http://www.lemonde.fr/idees/article/2017/11/24/robertbadinter-le-bagne-de-guyane-un-crime-contre-1-humanite_5219546_3232.html. Accessed: 7 April 2018.

Breleur, E., Chamoiseau, P., Domi, S., Glissant, É. et al. (2009). Manifeste pour les produits de 'haute nécessité. Paris: Éditions Galaade.

Chamoiseau, P. (1986). Chronique des sept misères. Paris: Gallimard. . (1992). Texaco. Paris: Gallimard. Translated by Réjouis R.-M and Vinokurov, V. (1997) London: Granta. . (1997). Ecrire en pays dominé. Paris: Gallimard. . (1997). L'Esclave vieil homme et le molosse. Paris: Gallimard. . (2003). Biblique des derniers gestes. Paris: Gallimard. . (2007). Préface'. Prison vue de l'intérieur: Regards et paroles de ceux qui travaillent derrière les murs. Paris: Albin Michel. . (2007). Un dimanche au cachot/ Paris: Gallimard. . (2012). L'empreinte à Crusoé. Paris: Gallimard. . (2014). Mondialisation, mondialité, pierre-monde. Littérature 174. 92-103. . (2017) Frères Migrants. Paris: Seuil.

Chamoiseau, P. and Hammadi, R. (1994). Guyane: Traces-mémoires du bagne (Paris: Caisse nationale des monuments historiques et des sites. 
Cobb Wittrock, Mary. (2010). Frankétienne's spirals: chaos theory, minor literature and generic limits. International Journal of Francophone Studies 13:1. 103-129.

Davis, A.Y. (2003). Are Prisons Obsolete? New York, NY: Seven Stories Press.

Derrida, J. (1976). Of Grammatology. Translated by Spivak, G.C. Baltimore, MD: Johns Hopkins University Press.

Donet-Vincent, D. (1992). La fin du bagne, 1923-1953. Éditions Ouest-France.

Douglas, R. (2009). Frankétienne and writing: A work in progress. New York, NY: Lexington Books.

Feyereisen, J. (2017). Corps en captivité : Patrick Chamoiseau et J.M.G. Le Clézio. Sens Public. doi:10.7202/1048847ar.

Forsdick, C. (2018). Postcolonializing the Bagne. French Studies 72:2. 237-255.

Glissant, É. (1997). Le discours antillais. Paris: Gallimard.

Glissant, É. (1997). Poétique IV. Traité du Tout-Monde. Paris: Gallimard.

Glissant É and Chamoiseau, P. (2007). Quand les murs tombent: L'identité nationale hors la loi. Paris: Éditions Galaade.

Harkins, G. and Meiners, E.R. (2016). Teaching Publics in the American Penalscape. American Quarterly 68:2 (June). 405-408.

James, J. (2007). Warfare in the American Homeland: Policing and Prison in a Penal Democracy. Durham, NC: Duke University Press.

Knepper, W. (2012). Patrick Chamoiseau: A Critical Introduction. Jackson, MS: University of Mississippi Press.

Kullberg, C. (2013). The Poetics of Ethnography in Martinican Narratives: Exploring the Self and the Environment. Charlottesville, VA: University of Virginia Press. Laguarigue, J.-L de (with P. Chamoiseau). (2011). Bagne A.P. Paris: Gang. McCusker, M. (2007). Patrick Chamoiseau: Recovering Memory. Liverpool: Liverpool University Press. 
Milne, L. (2006). Patrick Chamoiseau: Espaces d'une écriture antillaise. Amsterdam and New York, NY: Rodopi.

Moran, D., Turner, J., and Schliehe, A.K. (2018). Conceptualizing the carceral in carceral geography. Progress in Human Geography. 42:5. 666-686.

Observatoire International des Prisons. (2018). Nouvelle-Calédonie: Camp-Est ‘Bagne postcolonial.’ 20 March. Available: https://oip.org/analyse/nouvelle-caledoniecamp-est-bagne-post-colonial/. Accessed 19 October 2018.

Parry, J. (2019). Ruinology. Philosophy Today. 63:4. 1081-1091.

Pierre, M. (2017). Le Temps des bagnes, 1748-1953. Paris: Tallandier.

Sanchez, J.-L. (2013). A perpétuité - Relégués au bagne de Guyane. Lyon: Vendemiaire.

Sanyal, D. (2014). Auschwitz as Allegory in Night and Fog.' In Concentrationary Cinema: Aesthetics as Political Resistance in Alain Resnais' Night and Fog, edited by G. Pollock and M. Silverman. New York, NY: Berghahn Books. 152182.

Selao, C. (2015). Enfermement et liberté dans l'oeuvre de Patrick Chamoiseau. In Écritures de la reclusion edited by I. Bazié and C. Ferrer. Presse Universitaires du Québec, 27-46.

Simek, N. (2016). Irony in the Dungeon: Anamnesis and Emancipation. In Bourdieu and Postcolonial Studies edited by R. Dalleo. Liverpool: Liverpool University Press. 191-208.

Silverman, M. (2015). Palimpsestic Memory: The Holocaust and Colonialism in French Fiction and Film/ Oxford and New York, NY: Berghahn. . (2010). Memory-Traces: Patrick Chamoiseau and Rodolphe Hammadi’s Traces-Mémoires du bagne. Yale French Studies 118/119. 225-238. 
Spieler, M. (2012). Empire and Underworld: Captivity in French Guiana. Cambridge, MA: Harvard University Press.

Stafford, A. (2010). Photo-Texts: Contemporary French Writing of the Photographic Image. Liverpool: Liverpool University Press. 
${ }^{\mathrm{i}}$ Roads, pistes, railways, drainage works, building construction, canals, dikes, maintenance of villages, commercial and administrative activities, artistic testimony... there is not a single space that didn't benefit from the industry of a convict.

ii Blockhouse...Library...Disciplinary Quarter...Tribunal... Special Quarter... Words divide up the space.

iii A common misconception is that the Camp de la Transportation was taken over by squatters.

iv Unless otherwise stated, all translations are my own.

${ }^{\mathrm{v}}$ Fortunate were those writing under the domination of the previous age: their poems could as bullets, comforting the hopes of many with their impact.

${ }^{\text {vi }}$ Stone, since beyond the possibility of human representations.

Stone, since already there yet still to be built.

Stone, since fluid and uncertain and of high density.

Stone, since in us and around us, in desire and material.

Stone, since of shadows and light, conscious and unconscious, of chaos and opposites

Within the Unity that we find inconceivable.

Stone, since of consciousness pushed towards an awareness of a primordial material $/ \mathrm{matter}$.

${ }^{\text {vii }}$ Amerindians, African slaves, Hindu immigrants, Syro-Lebanese, Chinese...

viii In the shadow of the cell, the quadrillage of the bars through which the light shines. Square, rectangle or half-moon. It is not only the light which the bars distort, but the wind, the odours, bits of sky, slices of wall, squares of life that are so often motionless.

ix The camps without barbed wire of systemic unemployment belonging to capitalism.

${ }^{\mathrm{x}}$ This claim is nevertheless somewhat disingenuous given the clearly marked entrance to the Camp de la Transportation in Saint Laurent du Maroni.

${ }^{x i}$ Allow me not to go into details about the dungeon, Marie-Sophie, because you see those things are not to be described. Lest, we ease the burden of those who built them. (50)

${ }^{\text {xii }}$ Ah... And what does that change?' 
xiii My imagination taking hold of objects and my obscure memory produced only chaos: all possibility of shedding light on my real origins thus disappeared...

xiv enlarging the spaces in between phrases, words and their realities...

${ }^{\mathrm{xv}}$ Nothing looks more like an island than another island.

${ }^{\text {xvi }}$ I told myself repeatedly that this was a living organism, not a desert island, not a hostile prison but a life that had succeeded in emerging from a soulless lava...

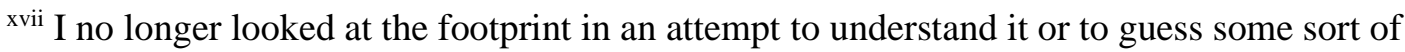
origin, it was placed there, inscribed in the clay mass covered by sand, it had no age, no beginning or end, probably it had been there since before I came into existence, perhaps it hailed from the prehistory of this world, and its resemblance to the form of a foot belonged only to my poor imagination. I forced myself to simply perceive it for what it was, an ineffable form, planted there, onto the time and surface of the world...

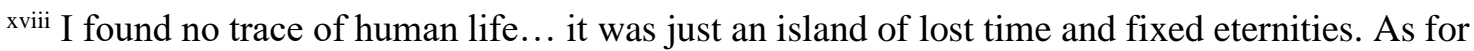
the footprint, we were unable to locate it anywhere. 